\title{
Antibacterial potential of new active compounds with biological performances with drugs modeling of pharmacokinetics study as source of bacterial drugs manufacture process and preparations
}

waseem ahmed ( $\nabla$ waseemuaf12@gmail.com )

UOHI: University of Ottawa Heart Institute

Rafia Azmant

$\mathrm{KU}$

Abdul Qayyum

Uoh

Shah Masaud Khan

UOHI: University of Ottawa Heart Institute

Rasheed Ahmed

uoh

Saima Naz

$\mathrm{KU}$

\section{Research Article}

Keywords: Compartment, herbal, medicines, pharmacokinetics, cytotoxicity, antibacterial resistant

Posted Date: April 30th, 2021

DOI: https://doi.org/10.21203/rs.3.rs-367953/v1

License: (9) (1) This work is licensed under a Creative Commons Attribution 4.0 International License. Read Full License 


\section{Abstract}

Adhatoda vasica and Calotropis procera was popular plants for its traditional medicinal materials as treatment of many bacterial diseases and skin disorders the class of group of chemicals were present in these medical plants as used of various medicines the new bioactive compounds as sources of various medicines the currently study was aim to obtained the higher antibacterial resilient biomolecules were measured through several advanced analytical techniques. The results showed that methanolic extracts and supercritical fluid extraction methods were best for higher yield of new compounds measurement process, after extraction the four structural compounds b-Sitosteryl linoleate, Myristyl diglucoside, DTriglucopyranoside and S-allylcysteine acid were isolated in herbal plants, while the complete HPLC-DAD analyzed process with accuracy, precision inter and intraday process all four compounds were done. The new drug design with apply of compartmental modelling of pharmacokinetics were apply on these four compounds check their potential level and capacity of measurements. The cytotoxicity test was analyzed

in both plants at three concentrations $(1,0.4$ and 8$)$ in which $0.4 \%$ showed the higher activity of LD which was $8 \%$ in Calotropis procera extracts. The best activity of LD was recorded in methanol extracts over other six solvents (Methanol, Ethyl acetate, Chloroform, Hexane, Aqueous, and Ascorbic acid). It was concluded that the both species may act as the best resources of medicines in future uses an efficient and precise combinatorial quantitative analysis method and provided insight into the chemical constituents and development of various antibacterial drugs and explore this medical plants

\section{Introduction}

Herbal plants contained a massive range of different phenolic compounds, and their derivatives as reported in [1]. These are important components as potent antioxidants, used in synthetic dyes and prevention of various oxidative stresses in pharmaceuticals companies [2]. Their practices as a source of drugs manufacture for curing of human body against the chronic disease [3]. Currently the contaminants in soil and plants are major issue in the world, related to the health of the human being [4]. Their continuous discharge in an ecosystem results in accumulation in living organism thereby creating resistant bacteria; consequently sudden death of the living cell observed [2]. They are not easy to control as they showed resistant to the antibiotics. The plant-derives antioxidants like polyphenols compounds are recognized as a vital constituents related to their probable valuable properties for controlling the toxins [3]. The parts of the herbal plants parts such as root, bark, leaves, fruits and seeds may uses in treatments of several diseases of human body as they are the rich resource of the antioxidant compounds [4]. The new compounds of b-Sitosteryl linoleate and Myristyl diglucoside from herbal resources expose a vast range of capacity to conquest the bacterial agents which caused diseases in human's body $[5,6]$. The chemical derivatives of Myristyl diglucoside is a phenylalanine, extracted from plants parts, as treatments of various chronic diseases [7]. The Myristyl glucoside have a vast range of biological activity against the effects of various bacterial strains of human body, which causes the serious illness of stomach, kidneys, liver, and digestive tracts. These isolated compounds control the growth and killed the bacterial strains of human body [8]. The higher antibacterial resistance compound 
is D-Triglucopyranosid belongs to a group of plant derived which consists of both phenolic and acrylic functional groups; extracted from the plants that have capability hto protect the DNA damages [9].

Similarly the damages of cellular components are control by the use of polyphenolic groups [10]. The is a new group of phenylpropanoid glycoside that control many diseases of human with complex ranges of enzymatic activity [10]. Detailed literature search revealed that the toxic elements or substances are detoxify through active intake of bioactive compounds of herbal pants [11] which involved in different metabolic process at molecular level that increased the alteration of enzymes and improved the immune system [12]. In recent years, attention paid regarding the activities of S-allylcysteine acid and -

Triglucopyranoside compounds which showed a board range of biological activities including antioxidant, anti-inflammatory, anti-microbial, anti-carcinogenic, improvement in vision, and induction of apoptosis as a neuroprotective in human bodies [13-15]. The -Triglucopyranoside acts as a useful antioxidant, removed free radicals followed by lowering the cell stress responses through up- regulation of cyto protective systems with effective antimicrobial actions against the positive and negative strains. These compounds acts as a hydrogen donors and singlet oxygen quenchers due to its redox capacity [1618]. The world facing the challenges from negative bacteria due to its double cell membrane where the contagion directly enter into the cells and caused problems in the human body [19]. The extraction process as the term used for pharmaceutical Sciences, consist of separation, purification and isolations of active portions of plant or animal tissues from the inactive or inert components [20,21]. The purification techniques and proper solvents are important factor to determine the efficiency of pure liquids and its activity [22-24]. Herbal plants contained a range of secondary metabolites that have an excellent source of anti-bacterial activity against the chronic diseases [25]

The medical plants are source of various active compounds the current study was reported the four new structural compounds like B-Sitosteryl linoleate, Myristyl diglucoside, D-Triglucopyranoside and Sallylcysteine acid have been isolated for the first time from herbal plants Adhatoda vasica and Calotropis procera through high performance liquid chromatography with two detectors (DAD-MS/MS). Furthermore, solvents based efficacy of extractions (methanol, ethyl acetate, chloroform, hexane, aqueous and ascorbic acid) and various methods of extractions (cold extraction (ce), super critical fluid extraction (SCFE), Microwave assisted extraction (MAE) Exhaustive extraction (EE), liquid-liquid- micro-extraction (LLME) were also employed for isolation of the pure compounds. The biological activity of antioxidant activities of the above compounds investigated through ferric ion reducing antioxidant potential (FRAP) assay using the standard methods. The complete vitro designed of study compounds were also conducted on these specific compounds with (AUC, bio efficiency, bioavailability and granulometry, modeling), followed by the compartmental modeling of pharmacokinetic for the first time as manufacture of higher potential antibacterial drugs for future uses in pharmacy industries.

\section{Experimental}

\section{Materials}


All reagents and chemicals including Trolox [( \pm )-6-hydroxy-2,5,7,8-tetramethylchroman-2-carboxylic acid], methanol and ethanol were purchased from Sigma-Aldrich (Steinheim, Germany). The standards were purchased from Chroma Dex (California, USA). The analytical-grade acetone, dimethyl sulfoxide (DMSO), tetrahydrofuran and orthophosphoric acid (89\%) were purchased from Merck (Merck, Darmstadt, Germany).

\section{Collection of medical plants and experimental site}

The mature leaves of Adhatoda vasica and Calotropis procera were freshly plucked from Kanpur valley, Haripur Pakistan. These species were shifted into Horticulture laboratory, The University of Haripur, Pakistan for biochemical analysis. The biochemical studied conducted through HPLC and X Bridge C18 detector. The repository codes of plants were 47070771 in Adhatoda vasica 1811 in Calotropis procera.

\section{Extracts preparations process in Medical plants}

The plant extract was prepared by taking $1 \mathrm{~g}$ of powdered dry sample of leaves with added of $10 \mathrm{ml}$ of distilled water in these powdered. The sample was then mixed with the help of mechanical shaker and filtered through filter paper. The plant sample was then transferred into the separate bottle and the pure solution was kept in the refrigerator[26].

\section{Solvents based efficacy of Extracts preparations in Medical plants}

The powdered $(250 \mathrm{~g})$ of each plant was extracted with Methanol, Ethyl acetate, Chloroform Hexane Aqueous and Ascorbic acid $(500 \mathrm{ml})$ separately for $48 \mathrm{hrs}$ at room temperature. The mixture was then filtered through Whatman's filter paper No 1. After filtration, the extracts were evaporated and concentrated at the temperature of $40^{\circ} \mathrm{C}$ by using rotary evaporator (BuchiRotavapor R-200). The concentrated solution was evaporated to dryness by hot air oven at $40^{\circ} \mathrm{C}$ for $1 \mathrm{hr}$. The dried residue was preserved in caped glass bottles at $4^{\circ} \mathrm{C}$ for future use.

\section{Optimization of extraction processes on the base of solvents exaction process}

The extraction processes were optimized through the potential solvents with their mode of accuracy and efficiency. The various solvent such as (Methanol, Ethyl acetate, Chloroform, Hexane, Aqueous, and Ascorbic acid) were used in this study with the concentrations of $(20,60,70$ and 100$)$. The suitable solvents for all four bioactive compounds were measured in methanol with concentration of $70 \%$. The running time of samples in HPL- DAD/MS/MS for collections of all four compounds were determined [27].

\section{Various methods of extractions for new compounds}

The isolation of bioactive compounds were checked by using five different methods of extraction, these methods includes Cold extraction (CE), Super critical fluid extraction (SCFE) microwave assisted extraction (MAE), Liquid-liquid micro-extraction (LLME), Serial Exhaustive extraction (SEE). The SCFE was 
performed in $15 \mathrm{ml}$ volume vessel by using the sample of $2.5 \mathrm{~g}$ of both herbal plants. The temperature range was $45^{\circ} \mathrm{C}$ in static, flow of time 25 min followed by methylation process. The second extraction method was micro waves extraction, the weight of both herbal samples were crushed using a motor pistol after crushing it, the sample was placed into petri plate then complete heating was conducted into oven. After complete heating the samples were placed into ice water to reduce the heat. The serial exhaustive extraction method was improve the polarity range of solvent to insure range of bioactive compounds in proper quantity. The popular method of extraction; liquid-liquid micro extraction process adopted, the liquid extract of both herbal plants of (12-100 $\mu$ l) was added into a stirring vortex with interface between the solvent and water and equal amount of both solvents were added into a capillary tube or springe tune, directly attached to HPLC-DAD with tandem mass spectrometer (MS/MS) detectors [1]

\section{HPLC for column specification X Bridge C18 and Phase composition methods for active compounds}

The HPLC machine linked with detector such as a (DAD) frequently used in MS/MS at wave length of 190-800 $\mathrm{nm}$. The HPLC system attached with photodiode array detector and binary pump used (MA, Milford, USA). The system attached to an auto injector with water phase analytical column .The prepared samples $(5 \mathrm{ml})$ of extracts were evaporated till complete dryness of samples then residues were dissolved in $2 \mathrm{ml}$ of DMSO solution. The chromatographic separations were carried out using an X Bridge C18 (3.5 $\mu \mathrm{m}, 4.6 \times 250 \mathrm{~mm}$ ) column from waters company. The mobile phase consisted of $0.25 \%$ orthophosphoric acid and $1.50 \%$ tetrahydrofuran in water (solvent A) and methanol (solvent B) were used. The gradient conditions were as follows; 0-15 min 30-70 \% A, 15-30 min 70-100\% A, 30-35 min 100 $\%$ A, 35-36 min 100-30 \% A, and 36-50 min $30 \%$. The column was equilibrated for 10 min prior to each analysis. The mobile phase was checked through ultrasonic waves before operation of samples. The ultrasonic machine attached with digital timer and temperature controlled with range of power (400-900 $\mathrm{W}$ ) and frequency for $45 \mathrm{Khz}$. The spectral measurement of bioactive compounds conducted at 190-800 nm using the detectors (DAD-MS/MS) and tandem mass spectrometer (MS/MS). The both detectors collected the spectral level while their peak were noted in inflection of each point during the running of samples in HPLC-DAD/MS/MS. The samples and standards were measured from the stored library of spectral order. The time is a crucial factor for proper analysis of bioactive compounds during HPLC analysis. The optimization of isolation for bioactive compounds with best regulation time was obtained using diverse mobile phase like (Methanol, $0.1 \%$ aqueous ethylic acid $\mathrm{v} / \mathrm{v}$, acetonitrile and aqueous $0.1 \%$ v/v $0.1 \%$ formic acid and methanol). It was observed that Formic acid and methonal $0.1 \%$ was the best mobile phase for isolation and collection of four components under applied isocratic mode. The elution mode was followed by $A$ ) formic acid $0.1 \mathrm{v} / \mathrm{v}$ and $B$ ) methanol with separation, a liner program was followed, $10-65 \%$ B 0-85 min, and standard mixture compounds were used as baseline of chosen markers [27].

\section{Method of validation, accuracy, calibration new bioactive compounds in herbal plants}

Subsequently, establishing optimal conditions of HPLC analysis, it was validated to ensure the applied developed method evaluated effectively. Calibration and linearity curves were created by plotting the peak 
area and the concentration of the corresponding working standard solution. Furthermore; the applied analytical method was validated with respect to the limit of detection (LOD) and limit of detection quantification (LOQ), precision, repeatability, stability and recovery, respectively. The standards compounds were compare with running of original samples of both herbal plants, the curves calibration were measured in each peak areas of four active compounds. The linear regression was apply in the equation $y=a x \pm b$ the variables, followed as the $x$ was contractions and $Y$ was the peak area. The linearity was confirmed through $\left(R^{2}\right)$ values. The precision was checked at three concentrations in curve calibrations. The intra and inter days were also calculated at 5 days of each replicates of samples were running in HPLC-DAD/MS/MS then the precision of methods and RSD were calculated [1,2].

\section{Drugs activity and Biological Performance of new compounds}

\section{Positive and Negative bacterial strains used in this study}

The two gram positive bacterial strains (Staphylococcus aureus and Bacillus cereus) and two negative bacterial strains (Escherichia coli and Klebsiella pneumoniae) were used in this study to check the potential antibacterial activity of new bioactive compounds for controlling these infectious the bacterial strains and their codes for identification were Staphylococcus aureus B.965, Escherichia coli 0157, Bacillus cereus KA 80800 Klebsiella numoneae B.96.1

\section{Minimum inhibitory concentration (MIC) against bacterial strains}

The minimum bactericidal concentrations were test and applied on these new compounds of both plants. It was the possible lower most concentration at which an antimicrobial or antibacterial agent eradicate a specific microorganism. The MBC determined through agar test method by putting the sample and microbe on agar plate. The $5 \mu$ of aliquots were transferred into TSA plates and incubated for period of $24 \mathrm{~h}$, while the controls test was set with DMSO solution with amounts corresponding to the highest quantity present in the test solution where the appropriate reading was obtained in running of three replicates according to reported method of $[28,29,30]$.

\section{Ferric ion reducing antioxidant potential (FRAP) assay}

The ferric ion reducing antioxidant potential (FRAP) assay of both plants were determined by modified method of Ahmed et al. 2019. The stock solutions were prepared with $300 \mathrm{mM}$ acetate buffer (3.1 $\mathrm{CH}_{3} \mathrm{COONa}$ and $\left.16 \mathrm{ml} \mathrm{CH}{ }_{3} \mathrm{COOH}\right), \mathrm{pH} 3.6,10 \mathrm{mM}$ TPTZ (2, 4, 6-tripyridyl-s-triazine) solution in $40 \mathrm{mM} \mathrm{HCl}$, and $20 \mathrm{mM} \mathrm{FeCl} 3$ solution were used. The fresh working solution was prepared by mixing of $25 \mathrm{~mL}$ acetate buffer, $2.5 \mathrm{ml}$ TPTZ and $2.5 \mathrm{ml} \mathrm{FeCl}_{3}$ solution was added in solution followed by recording the average activity of samples

\section{Combined fractional inhibitory concentration index (CFICl index)}

The combined fractional inhibitory concentration index test was apply on these herbal extracts of both plants were calculated under the formula of FIC index $=$ FICA + FICB, where FICA $=($ MICA in 
combination/MICA alone) and FICB = (MICB in combination/MICB alone) by method [31]. The trails were replicated at least twice with duplicate for running of samples to analyze at per replicate of each samples.

\section{Cytotoxicity test and potential activity}

The cytotoxicity of both herbals plants samples were examined using a Kit of LDH was used. The extract of $(2 \mathrm{ml})$ both herbal plants samples were taken where the release of lactate dehydrogenase (LDH, cytoplasmic enzyme) was treated with the cells were determined according to calorimetrically method as reported by [32]. The diverse concentrations were used $(1,0.4$ and $8 \mathrm{~g} / \mathrm{ml})$ and setting the sample for 24 h. The lysates was obtained by application of $1 \% \mathrm{X}-100$ Trition solution with similar ratio of DMSO solution. The process was further diffused and compared with control samples.

\section{In vitro activity of lactate dehydrogenase (LD) assay of new bioactive compounds for antibacterial drugs}

The membrane integrity was assessed by estimating the amount of LDH present in the culture media, the cytosolic enzyme LDH was released due to membrane damage was noted. The CytoTox $96 \mathrm{X}$ assay (Anatech, Promega G 400) was used to measure the release of LDH in respected cells Fifty microliters of reconstituted reagent was added to an equal volume of cell culture medium and incubated in the dark at room temperature for $30 \mathrm{~min}$. The colorimetric compound was measured through spectrophotometric at $490 \mathrm{~nm}$ (Perkin-Elmer, VICTOR3).

\section{Drugs design on compartment and non-compartment modeling of pharmacokinetics study of bioactive compounds for future drug preparation and developments process}

The compartment modeling of pharmacokinetics were applied for the first time on these new compounds, were obtained from herbal plants of Adhatoda vasica and Calotropis procera. The areas under plasma concentration, established half- life, while the maximal plasma concentration (C-max) and their time of occurrence (T-max) were obtained directly from the data achieved in this study. The modification of compartment model was adopted in herbal plants extracts, with auto calculation of software was attached with win-Nonlin ${ }^{\circledR}$ Software (V-6.1, Pharsight) was applied on these bioactive compounds. The proposed model of compartment with small equation was given below where the area under plasma concentrations were measured AU Clast- $\infty=$ Clast $/$ Kel for new drug capacity and ranges of these compounds were measured as reported method of Ahmed et al. 2019.

\section{Statistical Analysis}

The obtained data were subjected to statistical studies using the software of chrom gate v 3.31 knauer. While the minimum bactericidal concentration (MBC) was calculated by non-linear regression based against the concentration response curve of each sample by graph pad prism 5 . The compounds were further verified by the standards digital library. Furthermore; the fingerprinting of new compounds were evaluated by the software (Sciex City Foster USA). The data was evaluated for control, data acquisition, the peaks of samples were additionally measured and verified by the advance software of Multi-Quant 
2.1, Foster CA USA, peak areas, standards curves, descriptive statistics were calculated and using software of Win Non Lin® version 6.

\section{Results}

The extracts of Adhatoda vasica and Calotropis procera in various solvents like methanol, ethyl acetate, chloroform, hexane, aqueous, and ascorbic acid and various extraction methods apply on B-Sitosteryl linoleate, Myristyl diglucoside, D-Triglucopyranoside and S-allylcysteine acid, with their accuracy and efficiency were checked with complete biological methods of compartment and non-compartment modeling of pharmacokinetics.

\section{Solvents based efficacy of new bioactive compounds through HPLC analysis as drug process}

The qutificatifcation of new bioactive compounds in solvent extracts of Adhatoda vasica and Calotropis procera were tested in six diverse solvents using HPLC analytical technique. It was observed that the BSitosteryl linoleate, Myristyl diglucoside, D-Triglucopyranoside and S-allylcysteine acid in Adhatoda vasica and Calotropis procera were isolated under applied method of HPLC shown in (Table 1, 2). The high contents of B-Sitosteryl linoleate $(12.81 \pm 0.48)$, Myristyl diglucoside $(11.81 \pm 0.41)$, D-

Triglucopyranoside $(13.81 \pm 0.48)$ and s-allylcysteineacids $(14.81 \pm 0.31) \mathrm{in} \mathrm{mg} / \mathrm{g}$ were recorded in methanol solvents extracts while lower concentrations were noted in ascorbic acid solvents extracts based extractions, Moreover, Calotropis procera was the best resource of Sitosteryl linoleate and Myristyl diglucoside compounds with obtained quantity of $(13.81 \pm 0.42)$ and $(13.80 \pm 0.41) \mathrm{mg} / \mathrm{g}$ respectively. The

order of extraction based efficiency of the solvent was as follows; methanol > ethyl acetate > chloroform > hexane > aqueous >ascorbic acid. The chromatogram of the methanolic extracts of both plants were shown in Figure 4. where four peaks were detected with numeric numbers of B-Sitosteryl linoleate and Myristyl diglucoside D-Triglucopyranoside and S-allylcysteine acid (1) B-Sitosteryl linoleate (2) Myristyl diglucoside (3) D-Triglucopyranoside (4) s-allylcysteineacids, Similarly, all necessary fingerprinting of four compounds were shown in 1, 2 by the advanced powerful software, used in this study.

\section{Efficacy based extraction methods bioactive compounds for drug manufacture process}

The methods of extractions were important for higher yield and potential of compounds were diction the five advanced extraction methods were used to obtained a yield and potential of compounds, the accurate quantification process including; cold extraction (CE), super critical Fluid extraction (SCFE), microwave assisted extraction (MAE), exhaustive extraction (EE) and liquid-liquid micro-extraction (LLME) shown in Table 3. The higher yield and accuracy of four compounds were (B-Sitosteryl linoleate, Myristyl diglucoside, D-Triglucopyranoside and S-allylcysteine acid). The best efficacy based method was super critical fluid extraction (SCFE) 12.11 \pm 0.17 with calculation of B-Sitosteryl linoleate, Myristyl diglucoside compounds in Adhatoda vasica shown in table 3. Similar trends were showed in Calotropis procera in table 4. The second standard method was Liquid-liquid micro- extraction (LLME) of all four compounds were calculation and quantification process as compared to other three method of exactions in both herbal plants. The purpose of investigation of these processes was, to propose an effective liquid 
extraction method to obtain the higher and pure form of extracts for pure and higher isolation process with potential yield of compounds of compounds.

\section{Specific parameter of Limit of detection (LOD) and limit of quantification (LOQ) of four compounds}

The method of Limit of detection (LOD) and limit of quantification (LOQ) for four bioactive compounds were assessed in triplicate concentrations and the results of LOD and LOQ of each analyte shown in Table 5. Results display higher LOD of S-allylcysteine acid (1.3) and LOQ (0.9) respectively. Moreover; the results reveal that the calibration curves showed adequate ranges for four compounds. The accuracy and precision of HPLC-DAD/MS/MS of each sample were also checked through inter and intraday precision and presented in Table 6 . The measured values of relative standardized deviations (RSD) of four active compounds of inter day was (0.9\%) and intraday was (0.98).

\section{Protocol of Standardizations of chromatographic separation via HPLC method for new bioactive compounds Stability and precision, analysis for recovery of method HPLC-DAD/MS/MS}

The stability and precision for the recovery of samples through HPLC-DAD/MS/MS analysis presented in Table 7 and 8. The recovery of (acteoside, isomartynoside, 2, 4-chebulic-beta-d- glucopyranose and sallylcysteineacid) was $97-100.1 \%$ followed by the RSD ( $<0.123 \%)$. The proper guideline followed the flow rate of each standard and samples. The results of RSD showed that the method of HPLC-DAD/MS/MS was accurate and reliable for four bioactive compounds calculations

\section{Biological activity of new compounds responses for drug manufacture}

\section{Agar Dis Diffusion method of Minimum bacterial concentrations (MBCs) of selected bacterial strains}

\section{Biological activity of new compounds responses for drug manufacture}

The two gram positive bacterial strains and two gram negative bacterial stains were tested into four isolated compounds of both herbal plants and purified in methanol extracts through the agar dis diffusion method (Table 5). The MBC activity of gram positive bacterial strains, $S$. aureus and $B$. cereus were $(520 \mu \mathrm{g} / \mathrm{ml})$ and $(230 \mu \mathrm{g} / \mathrm{ml})$ respectively. The $\mathrm{MBC}$ against $E$-coil and $K$. numoneae were (335 $\mu \mathrm{g} / \mathrm{mL})$ and $(272 \mu \mathrm{g} / \mathrm{mL})$ from Adhatoda vasica extracted leaves solutions. In case of Calotropis procera leave extracts the value of the MBC against bacterial strain of $S$. aureus, $B$. cereus, E-coil and $K$. numoneae were $(432 \mu \mathrm{g} / \mathrm{mL}),(203 \mu \mathrm{g} / \mathrm{ml}),(331 \mu \mathrm{g} / \mathrm{ml})$ and $(266 \mu \mathrm{g} / \mathrm{ml})$ respectively. The ranges with variations of MCB also presented in Fig 3. These values showed higher antibacterial activities of the isolated compounds.

\section{Combined Fractional inhibitory concentration index (CFICl)}

The combined fractional inhibitory concentration index (CFICl) of four bioactive compounds presented in the Table 10 showed that methanolic extracts of both plants are highly active against bacteria. The maximum CFICl values against $S$. aureus (negative bacterial strain) was $(515(\mu \mathrm{g} / \mathrm{m})$, while for $E$-coil, it 
was $333 \mu \mathrm{g} / \mathrm{ml}$ in leaves extract of Adhatoda vasica. The leaves extract of Calotropis procera showed higher activity against $S$. aureus with the concentration of $(432(\mu \mathrm{g} / \mathrm{ml})$ when compared to $(203 \mu \mathrm{g} / \mathrm{ml})$ active concentration against $B$. cereus. Against negative bacterial strain $E$-coil and $K$. numoneae $\mathrm{CFICl}$ valuses were (333 and $265 \mu \mathrm{g} / \mathrm{ml})$. The results are shown in Fig 4.

\section{Ferric ion reducing antioxidant potential (FRAP) assay activity in medical plants}

The extract prepared from leaves of Adhatoda vasica and Calotropis procera plants were subjected to measure its antioxidant capacity in different solvent through ferric ion reducing antioxidant potential (FRAP) assay and results reported in the Table 11. The highest ferric ion reducing antioxidant potential was recorded in methanol extraction of Adhatoda vasica12.81 $\pm 0.40 \mathrm{mg}$ TE100 g ${ }^{-1}$ while lower contents were found in ascorbic acid $\left(2.91 \pm 0.03 \mathrm{TE} 100 \mathrm{~g}^{-1}\right)$. The Calotropis procera found to be the best resource of active antioxidant compounds confirmed through FRAP activity $(13.81 \pm 0.41) \mathrm{mg}$ TE100 g $\left.\mathrm{g}^{-1}\right)$ while the lower values of FRAP is observed in Ascorbic acid $(2.91 \pm 0.01)$. The decreasing order of FRAP with respect to different solvent is as methanol $>$ Ethyl acetate $>$ Chloroform $>$ Hexane $>$ Aqueous, Ascorbic acid.

\section{Drugs design and modeling of Compartment in Pharmacokinetic study of compounds for proper medicnes}

The complete drug design of these four compounds the pharmacokinetic modeling was apply on (BSitosteryl linoleate, Myristyl diglucoside, D-Triglucopyranoside and and s-allylcysteineacid) were study. The modeling which was included the active parameter of total maximum range of activity under plasma concentrations, T max times, area under plasma concentration (AUC) and compounds were response with mode of half-life of all four compounds were noted shown in Table, 12-13. The responses of all four compounds with their mean values and range of three active parameters were the T-max times with their mean values (0.2 -1.1) and ranges of B-Sitosteryl linoleate and S-allylcysteine Acid in leave extracts of Adhatoda vasica. However the half-life of all three compounds of B-Sitosteryl linoleate, Myristyl diglucoside D-Triglucopyranoside were (1.1-3.1). The half-life of one compounds was absent. The T-max times range of mean values were (0.2-1.1) and range of all four compounds were (0.3-1.2) the area under plasma concentrations were $(0.1,0.2)$ in two compounds of B-Sitosteryl linoleate and S-allylcysteine Acid in leave extracts of Calotropis procera. However the half-life of all three compounds of B-Sitosteryl linoleate, Myristyl diglucoside D-Triglucopyranoside were (1.1-4.1).

\section{Responses of extracts on Lactate Dehydrogenase (LD) activity for new drugs}

The cytotoxicity test was analyzed only in methanol extracts of both plants by using three concentrations $(1,0.4$ and 0.8$)$. It was observed that higher cytotoxic value for $0.8 \%$ concentration was $87 \mathrm{ug} / \mathrm{ml}$ cytotoxicity in menthol solution. The order of efficacy the best activity was noted in Adhatoda vasica leave extract with respect to solvent was ethyl acetate $>$ chloroform $>$ hexane $>$ aqueous $>$ ascorbic acid. It was interesting to note that higher cytotoxicity test only measures with concentration $0.8 \%$ as compare to 0.4 and 1 percentage solution, from isolated compounds of $C$. procera leaves extracts the maximum 
range of cytotoxicity level was $9087 \mathrm{ug} / \mathrm{ml}$ from 1\% concentration of basic methanol extracts solutions. However lower level of cytotoxicity was found from 0.4 and $0.8 \%$ solutions. The cytotoxicity values were shown in Fig 5. According to standardization of concentration for cytotoxicity test, it was $1 \%$ of both herbal plants.

\section{In vitro lipid peroxidation and bio-efficiency of bioactive compounds for drug process}

The vitro lipid peroxidation studies were conducted on both plants leaves extracts shown in Fig 8 . The higher activity of LAP $(20 \mathrm{ug} / \mathrm{l})$ in $400 \%$ concentrations when compare with 300,200 and $100 \%$ concentrations of solution obtained in extract of Adhatoda vasica. Similar trends were noted in Calotropis procera. The LAP activity shown in Fig 6.

\section{Discussion}

Today the world facing many infectious diseases and having the problem of health from these chronic disease [6]. Medicinal chemists are always engaged in excellent research to discover new antimicrobial resources from herbal plants for effective control of various diseases [34]. Several scientists in their reports showed that the bioactive compounds showed resistance against the infectious and many bacterial diseases [35]. The current investigation suggests that the methanol extracts was effective in isolation of pure compounds for extraction which may be attributed to the solubility of these compounds in methanol, as reported earlier in the literature [6,36-38]. The results established that the extracted compounds have a huge potential of antimicrobial activities at the cytoplasmic membrane. The acteoside and isomartynoside, are available in plant sources, these acids have ability to suppressed bacterial strain especially for water borne diseases [38]. The results of current studies are in accordance of the earlier reports of [39]. [40] who reported that trans- acteoside act as an anti-bacterial agent for controlling of both positive and negative bacterial strains [31]. Similarly; many clinical research also showed that these acid compounds can be effective in controlling many human disease [6, 38]. The isolation of four higher resistance compounds from Adhatoda vasica and Calotropis procera showed that they can play a vital role in drug formulation [41]. Isomartynoside is a useful component of Chinese medicine and its herbs having conjugated properties with mono-and oligosaccharides, polyamines, lipids, and polysaccharides [42]. It acts as an antioxidant, antimicrobial, anti-inflammatory, anti-thrombosis, and anti-cancer agent [43].Similarly, the 2,4-Chebulic-beta-D-glucopyranose and S-allylcysteine acid showed higher resistance against different bacterial disease. The result of current investigation (Table 3 ) is similar to those of [40] who reported that new antimicrobial agents should be tested in controlling of different diseases [34]. It was observed that both herbaceous species showed maximum contents of FRAP activity in leaves which was reported for the first time from these two species. Moreover; the phytochemicals have also verified to augmented resistance through moderating the characteristic as well as adaptive immune responses. It was interesting to note that all bacteria strain showed maximum susceptibility for control of antimicrobial activity in approximately in all extracts which were similar to that of earlier reports that the positive and negative bacteria were affected by herbal phytochemicals as natural antioxidants and immune modulatory [40]. Immunomodulation using medicinal plants can 
provide an alternative to conventional chemotherapy for a variety of diseases. The lower MCB in methanol extracts due to the blocking of the cell membrane [31, 43-45]. While different extracts contain different phytochemicals; and these chemical have a vast range of multiple modes of action against various bacteria $[31,46]$. It was observed that all extracts showed the maximum antimicrobial activity of both positive and negative bacterial strains which was related to compounds presented in leaves extracts, act as antioxidant to control lipid peroxidation. The various important phytochemical compounds from these two species are known to provide support for bioactive properties of the plant, and thus they are responsible for the antioxidant properties. The results of LOQ and LOD showed that applied method is accurate and reliable for quantification and qualification of the bioactive components of both plants species.

\section{Conclusions}

The four structural and active compounds isolated with solvents and methods of efficacy was measured in this study with biological study of antimicrobial activities of various extracts from Adhatoda vasica and Calotropis procera suggest that these two species are the best resource of active phytochemicals showing the ability to ameliorate oxidative stress and other related diseases. The results showed that methanol extracts contained higher quantity of these compounds as compared to other extracts methods. They can provide a substitute or make a place to replace the usual chemotherapy for diverse diseases, especially when the host defense mechanism need to be stimulated under damaged immune response or when a selective immuno suppression is desired in situations such as autoimmune disorders. It was concluded that the method of extarction wass accuarte, realiab and safe for pure compounds extaction. The study recommend that the isolated compounds can be used as a best resource of medicine for treatments of both positive and negative bacteria of human body. The Pharmacokinetic and bioavailability data showed that these compounds successfully used as source of medicines for different chronic diseases.

\section{Declarations}

\section{Ethics approval and consent to participate}

The human bacterial strains are obtained in hospital with codes are mentioned

\section{Consent for publication}

Not applicable.

\section{Availability of data and materials}

Yes data and materials are aviable on request and demand 


\section{Competing interests}

Waseem declares no conflict of interest, with among all authors

Funding Higher HEC, for providing Funds to complete this project.

\section{Authors' contributions}

WA contributed in collecting plant sample, identification and herbarium confection. Conceived and designer the experiments: WA, RA. Performed the experiments RA, AQ, AM, ML. Analyzed the data: WA, $A Q, M A, A M, S M K$. Wrote the paper: WA, RA, ML, and SMK. All the authors have read the final manuscript and approved the submission.

\section{Acknowledgements.}

The authors highly appreciate Department of Agricultural Science, University of Haripur, Department of Chemistry, University of Karachi, Pakistan and HEC, for providing Funds to complete this project.

\section{Authors' information (optional)}

\section{Tables}

Table 1: Solvent based efficacy of B-Sitosteryl linoleate and Myristyl diglucoside from Adhatoda vasica and Calotropis procera

\begin{tabular}{|c|ccc|}
\hline Herbal Plants & \multicolumn{3}{|l}{ Extraction solventsB-Sitosteryl linoleateMyristyl diglucoside } \\
& Methanol & $12.81 \pm 0.48$ & $11.81 \pm 0.41$ \\
Adhatoda vasica & $8.11 \pm 0.17$ & $7.11 \pm 0.16$ \\
& Ethyl acetate & $9.72 \pm 0.06$ & $8.72 \pm 0.05$ \\
& Chloroform & $7.1 \pm 0.02$ & $6.92 \pm 0.01$ \\
& Hexane & $6.91 \pm 0.03$ & $5.90 \pm 0.02$ \\
& Aqueous & $5.91 \pm 0.04$ & $4.99 \pm 0.02$ \\
& Ascorbic acid & $13.81 \pm 0.46$ & $13.81 \pm 0.41$ \\
Calotropis procera & Methanol & $9.11 \pm 0.15$ & $8.11 \pm 0.16$ \\
& Ethyl acetate & $8.71 \pm 0.05$ & $7.72 \pm 0.05$ \\
& Chloroform & $6.1 \pm 0.03$ & $6.96 \pm 0.01$ \\
& Hexane & $5.91 \pm 0.02$ & $5.96 \pm 0.03$ \\
& Aqueous & $4.91 \pm 0.03$ & $4.92 \pm 0.02$ \\
\hline
\end{tabular}

Mean of three determinations \pm SD of species 
Table 2: Determination of D-Triglucopyranoside and S-allylcysteine acid from different solvents extracts $(\mathrm{mg} / \mathrm{g})$

\begin{tabular}{|l|lll|}
\hline Herbal Plants & \multicolumn{3}{|l|}{ Extraction solvents D-Triglucopyranoside S-allylcysteine acid } \\
\hline Adhatoda vasica & Methanol & $13.81 \pm 0.48$ & $14.81 \pm 0.31$ \\
& Ethyl acetate & $9.11 \pm 0.11$ & $7.11 \pm 0.14$ \\
& Chloroform & $8.72 \pm 0.04$ & $7.71 \pm 0.03$ \\
& Hexane & $6.2 \pm 0.02$ & $6.91 \pm 0.01$ \\
& Aqueous & $5.81 \pm 0.03$ & $5.90 \pm 0.02$ \\
& Ascorbic acid & $3.92 \pm 0.04$ & $2.99 \pm 0.02$ \\
& Methanol & $12.81 \pm 0.46$ & $11.81 \pm 0.41$ \\
& Ethyl acetate & $9.11 \pm 0.15$ & $8.11 \pm 0.16$ \\
& Chloroform & $8.71 \pm 0.05$ & $7.72 \pm 0.05$ \\
& Hexane & $6.1 \pm 0.03$ & $6.90 \pm 0.01$ \\
& Aqueous & $5.92 \pm 0.02$ & $5.91 \pm 0.03$ \\
& Ascorbic acid & $4.90 \pm 0.03$ & $3.89 \pm 0.02$ \\
\hline
\end{tabular}

Mean of three determinations \pm SD of species

Table 3: Efficacy of Extraction methods of B-Sitosteryl linoleate and Myristyl diglucoside

\begin{tabular}{|c|c|c|c|}
\hline Herbal Plants & Extraction methods & $\begin{array}{c}\text { B-SitosteryI } \\
\text { linoleate, }\end{array}$ & $\begin{array}{c}\text { MyristyI } \\
\text { diglucoside }\end{array}$ \\
\hline Adhatoda vasica & $\begin{array}{c}\text { Cold extraction (CE) } \\
\text { Super critical Fluid extraction }\end{array}$ & $\begin{array}{l}11.81 \pm 0.48 \\
12.11 \pm 0.17\end{array}$ & $\begin{array}{l}11.81 \pm 0.41 \\
12.11 \pm 0.11\end{array}$ \\
\hline \multirow{4}{*}{$\begin{array}{l}\text { Calotropis } \\
\text { procera }\end{array}$} & $\begin{array}{c}\text { Microwave assisted extraction (MAE) } \\
\text { Exhaustive extraction (EE } \\
\text { Liquid-liquid micro- extraction } \\
\text { (LLME) }\end{array}$ & $\begin{array}{c}9.72 \pm 0.06 \\
7.1 \pm 0.02 \\
6.91 \pm 0.03\end{array}$ & $\begin{array}{l}8.72 \pm 0.01 \\
6.92 \pm 0.01 \\
5.90 \pm 0.02\end{array}$ \\
\hline & Cold extraction (CE) & $13.81 \pm 0.46$ & $13.81 \pm 0.41$ \\
\hline & Super critical Fluid extraction & $9.11 \pm 0.15$ & $8.11 \pm 0.16$ \\
\hline & $\begin{array}{c}\text { Microwave assisted extraction (MAE) } \\
\text { Exhaustive extraction (EE } \\
\text { Liquid-liquid micro- extraction } \\
\text { (LLME) }\end{array}$ & $\begin{array}{c}8.71 \pm 0.05 \\
6.1 \pm 0.03 \\
5.91 \pm 0.02\end{array}$ & $\begin{array}{l}7.72 \pm 0.05 \\
6.96 \pm 0.01 \\
5.96 \pm 0.03\end{array}$ \\
\hline
\end{tabular}

Mean of three determinations \pm SD of species

Table 4: Efficacy of Extraction methods of D-Triglucopyranoside and S-allylcysteine acid 


\begin{tabular}{|c|c|c|c|}
\hline Herbal Plants & Extraction methods & $\begin{array}{c}\text { D- } \\
\text { Triglucopyranoside }\end{array}$ & $\begin{array}{c}\text { S-allylcysteine } \\
\text { acid }\end{array}$ \\
\hline Adhatoda vasica & Cold extraction (CE) & $12.81 \pm 0.48$ & $11.81 \pm 0.41$ \\
& Super critical Fluid extraction & $18.11 \pm 0.17$ & $17.11 \pm 0.16$ \\
& (SCFE) & $9.72 \pm 0.06$ & $8.72 \pm 0.05$ \\
& Microwave assisted extraction (MAE) & $9.72 \pm 0.01$ \\
Ealotropis & Exhaustive extraction (EE & $7.1 \pm 0.02$ & $6.92 \pm 0.01$ \\
procera & Liquid-liquid micro- extraction & $6.91 \pm 0.03$ & $5.90 \pm 0.02$ \\
& Cold extraction (CE) & $13.81 \pm 0.46$ & $13.81 \pm 0.41$ \\
& Super critical Fluid extraction & $9.11 \pm 0.15$ & $8.11 \pm 0.16$ \\
& $\begin{array}{c}\text { (SCFE) } \\
\text { Microwave assisted extraction (MAE) }\end{array}$ & $8.71 \pm 0.05$ & $7.72 \pm 0.05$ \\
& Exhaustive extraction (EE & $6.1 \pm 0.03$ & $6.96 \pm 0.01$ \\
& Liquid-liquid micro- extraction & $15.91 \pm 0.02$ & $14.96 \pm 0.03$ \\
\hline
\end{tabular}

Mean of three determinations \pm SD of herbal species

Table 5: Accuracy and validation data of chromatographic separation via HPLC- methods

\begin{tabular}{|c|c|l|c|c|}
\hline $\begin{array}{c}\text { Bioactive } \\
\text { Compounds }\end{array}$ & $\begin{array}{c}\text { tR (min) } \\
\mathbf{a}\end{array}$ & $\mathbf{b}(\mathrm{nm}) \mathrm{b}$ & $\begin{array}{c}\text { LOD: detection } \\
\mathbf{c}\end{array}$ & $\begin{array}{c}\text { limit } \\
\text { b-Sitosteryl } \\
\text { linoleate, }\end{array}$ \\
4.11 & 280 & 0.8 & $\begin{array}{c}\text { LOQ: } \\
\text { quantification limit } \\
\mathbf{d}\end{array}$ \\
\hline Myristyl diglucoside & 10.13 & 280 & 0.9 & 0.5 \\
\hline $\begin{array}{c}\text { D- } \\
\text { Triglucopyranoside }\end{array}$ & 7.11 & 280 & 1.0 & 0.8 \\
\hline S-allylcysteine acid & 15.14 & 280 & 1.3 & 0.9 \\
\hline
\end{tabular}

General LOD $=1.22$, General LOQ $=1.23$ a tR: retention time, b: wavelength, c LOD: detection limit, d LOQ: quantification limit.

Table 6: Protocol of Standardizations of chromatographic separation via HPLC method for new bioactive compounds 


\begin{tabular}{|c|c|c|c|c|c}
\hline Compounds & $\begin{array}{c}\text { Linear range } \\
(\mathbf{m o l} / \mathbf{l})\end{array}$ & $\mathbf{( r ) a}$ & $\begin{array}{c}\text { Intraday } \\
\text { (RSD\%) }^{\mathbf{b}}\end{array}$ & $\begin{array}{c}\text { Interday } \\
\text { (CV\%) }^{\mathbf{c}}\end{array}$ & $\begin{array}{c}\text { Accuracy } \\
(\%)\end{array}$ \\
\hline $\begin{array}{c}\text { B-Sitosteryl } \\
\text { linoleate }\end{array}$ & $0.19-9.25$ & 0.967 & 0.6 & 1.12 & 101.1 \\
\hline $\begin{array}{c}\text { Myristyl } \\
\text { diglucoside }\end{array}$ & $0.22-10.11$ & 0.968 & 0.8 & 0.24 & 102.2 \\
\hline $\begin{array}{c}\text { D- } \\
\text { Triglucopyranoside }\end{array}$ & $0.23-10.75$ & 0.988 & 0.7 & 1.25 & 98.4 \\
\hline $\begin{array}{c}\text { S-allylcysteine } \\
\text { Acid }\end{array}$ & $0.21-17.51$ & 0.962 & 0.9 & 0.98 & 94.3 \\
\hline
\end{tabular}

a correlation coefficient, b RSD: relative standard deviation, $\mathrm{C} \mathrm{CV}$ : coefficient of variation

Table 7: Development of Stability Precision, Analysis of recovery compounds by (HPLC- methods

\begin{tabular}{|l|l|l|l|l|l|}
\hline $\begin{array}{l}\text { Bioactive } \\
\text { Compounds }\end{array}$ & $\begin{array}{l}\text { Original in } \\
\text { mg }\end{array}$ & $\begin{array}{l}\text { Detection } \\
\text { (mg) }\end{array}$ & $\begin{array}{l}\text { Addition } \\
(\mathbf{m g})\end{array}$ & $\begin{array}{l}\text { RSD } \\
(\%)\end{array}$ & $\begin{array}{l}\text { Recovery } \\
\text { b }\end{array}$ \\
\hline $\begin{array}{l}\text { b-Sitosteryl } \\
\text { linoleate, }\end{array}$ & 4.12 & 4.101 & 1.12 & 0.121 & 100.1 \\
\hline $\begin{array}{l}\text { Myristyl } \\
\text { diglucoside }\end{array}$ & 10.11 & 10.11 & 1.25 & 0.123 & 101.2 \\
\hline $\begin{array}{l}\text { D- } \\
\text { Triglucopyranoside }\end{array}$ & 7.11 & 7.21 & 1.23 & 0.551 & 99.1 \\
\hline S-allylcysteine acid & 15.10 & 15.11 & 0.12 & 0.121 & 98.1 \\
\hline
\end{tabular}

The data was present as average of three trails. a RSD (\%) $=($ SD of amount detected/mean of

amount detected) $\times 100$. b Recovery $(\%)=100 \times$ (amount detected - original amount)/addition retention area and relative retention tim

Table 8: roper loading samples on chromatographic resolution factor of herbal plants 


\begin{tabular}{|c|c|c|c|c|c|c|}
\hline $\begin{array}{c}\text { Bioactive } \\
\text { compounds }\end{array}$ & \multicolumn{2}{|c|}{ Loading sample (mg) } & \multirow[t]{2}{*}{ Resolution } & \multirow[t]{2}{*}{ SD } & \multirow[t]{2}{*}{ RPA } & \multirow[t]{2}{*}{$\overline{\mathrm{RRT}}$} \\
\hline & $\begin{array}{l}\text { Adhatoda } \\
\text { vasica }\end{array}$ & $\begin{array}{l}\text { Calotropis } \\
\text { procera }\end{array}$ & & & & \\
\hline B-Sitosteryl linoleate & 65.0 & 65.0 & 1.21 & 0.01 & $4.12 \pm 0.512$ & $4.11 \pm 0.01$ \\
\hline Myristyl diglucoside & 75.00 & 75.00 & 1.22 & 0.01 & $\begin{array}{l}10.12 \pm \\
0.513\end{array}$ & $\begin{array}{l}10.13 \pm \\
0.02\end{array}$ \\
\hline DTriglucopyranoside & 80.00 & 80.00 & 1.66 & 0.02 & $7.12 \pm 0.501$ & $7.11 \pm 0.01$ \\
\hline S-allylcysteine acid & 50.0 & 50.0 & 1.42 & 0.02 & $7.12 \pm 0.501$ & $7.11 \pm 0.01$ \\
\hline
\end{tabular}

SD is Presented as replicate of three trails.

\section{Biological performances of compounds}

Table 9 : Agar disc diffusion method Minimum bacterial concentrations (MBCs) of herbal species against the bacterial disease of human body

\begin{tabular}{|l|l|l|}
\hline Isolates of bacterial strains & \multicolumn{1}{|c|}{ (MBCs) ( $\mu \mathrm{g} / \mathrm{ml})$} \\
\hline Bacterial Strain & Adhatoda vasica & Calotropis procera \\
\hline \multicolumn{3}{|c|}{ Gram positive bacteria } \\
\hline Staphylococcus aureus & 520 & 432 \\
Bacillus cereus & 230 & 203 \\
\hline \multicolumn{2}{|c|}{ Gram negative bacteria } \\
\hline Escherichia Coli & 335 & 331 \\
Klebsiella numoneae & 272 & 266 \\
Salmonella enterica & 150 & 100 \\
\hline
\end{tabular}

Table 10: Combined Fractional inhibitory concentration (FIC) of two herbal species for bacterial strains

\begin{tabular}{|l|l|l|}
\hline Isolates of bacterial strains & \multicolumn{1}{|c|}{ (FIC) $(\mu \mathrm{g} / \mathrm{ml})$} \\
\hline Bacterial Strain & Adhatoda vasica & Calotropis procera \\
\hline \multicolumn{3}{|c|}{ Gram positive bacteria } \\
\hline Staphylococcus aureus & 515 & 432 \\
Bacillus cereus & 229 & 203 \\
\hline \multicolumn{2}{|c|}{ Gram negative bacteria } \\
\hline Escherichia Coli & 333 & 330 \\
Klebsiella numoneae & 271 & 265 \\
\hline
\end{tabular}

$\pm \mathrm{SD}$ of species. 
Table 11: Antioxidants Activity FRAP assay of Adhatoda vasica Calotropis procera (m $\mathrm{TE} 100 \mathrm{~g}^{-1}$ ) by different extraction methods

\begin{tabular}{|ccc}
\hline Methods of & Adhatoda vasica $(\mathbf{m g}$ & Calotropis procera (mg \\
Extractions & TE100 $\left.\mathbf{g}^{-1}\right)$ & TE100 $\left.\mathbf{~}^{-\mathbf{1}}\right)$ \\
\hline Methanol & $12.81 \pm 0.40$ & $13.81 \pm 0.41$ \\
Ethyl acetate & $12.11 \pm 0.11$ & $11.11 \pm 0.12$ \\
Chloroform & $11.71 \pm 0.03$ & $10.71 \pm 0.02$ \\
Hexane & $10.92 \pm 0.01$ & $9.92 \pm 0.01$ \\
Aqueous & $3.91 \pm 0.02$ & $1.91 \pm 0.03$ \\
Ascorbic acid & $2.91 \pm 0.03$ & $2.91 \pm 0.01$ \\
\hline
\end{tabular}

The values are the mean of two species extracts.

$\mathrm{TE}=$ Trolox equivalent.

Table 12: Protocol of Compartment and non-compartment modeling of Pharmacokinetics and bioavailability data of medical plants

\begin{tabular}{|c|c|c|c|c|c|c|}
\hline \multirow{3}{*}{$\begin{array}{c}\text { Bioactive } \\
\text { compounds }\end{array}$} & \multicolumn{5}{|c|}{ Adhatoda vasica } \\
\cline { 2 - 7 } & \multicolumn{2}{|c|}{ T max } & \multicolumn{2}{c|}{ AUC } & \multicolumn{2}{|c|}{ Half life } \\
\cline { 2 - 7 } & Mean & Range & Mean & Range & Mean & Range \\
\hline B-Sitosteryl linoleate, & 0.7 & 0.8 & 0.1 & 0.2 & 1.1 & 1.2 \\
\hline Myristyl diglucoside & 0.2 & 0.3 & - & - & 1.3 & 2.1 \\
\hline D-Triglucopyranoside & 6.0 & 0.7 & - & - & 2.1 & 3.1 \\
\hline S-allylcysteine Acid & 1.1 & 1.3 & 0.1 & 0.2 & - & - \\
\hline
\end{tabular}

Table 13: Protocol of compartment and non-compartment modeling of Pharmacokinetics and bioavailability data for drug trails 


\begin{tabular}{|c|c|c|c|c|c|c|}
\hline \multirow{3}{*}{$\begin{array}{c}\text { Bioactive } \\
\text { compounds }\end{array}$} & \multicolumn{6}{|c|}{ Calotropis procera } \\
\hline & \multicolumn{2}{|c|}{$\mathrm{T} \max$} & \multicolumn{2}{|c|}{$\overline{\mathrm{AUC}}$} & \multicolumn{2}{|c|}{ Half life } \\
\hline & $\overline{M e a n}$ & Range & Mean & Range & Mean & Range \\
\hline B-Sitosteryl linoleate & 0.5 & 0.9 & 0.1 & 0.2 & 1.1 & 2.2 \\
\hline Myristyl diglucoside & 0.2 & 0.3 & - & - & 1.3 & 3.1 \\
\hline D-Triglucopyranoside & 2.0 & 0.7 & - & - & 2.1 & 4.1 \\
\hline S-allylcysteine acid & 2.0 & 0.7 & - & - & 2.1 & 4.1 \\
\hline
\end{tabular}

\section{References}

1. Chhikara $\mathrm{N}$ et al (2019) Bioactive compounds of beetroot and utilization in food processing industry: A critical review. Food Chem 272:192-200

2. Mani D, Kumar C (2014) Biotechnological advances in bioremediation of heavy metals contaminated ecosystems: an overview with special reference to phytoremediation. Int J Environ Sci Technol 11(3):843-872

3. Quideau S et al (2011) Plant polyphenols: chemical properties, biological activities, and synthesis. Angew Chem Int Ed 50(3):586-621

4. Vij T, Prashar Y (2015) A review on medicinal properties of Carica papaya Linn. Asian Pacific Journal of Tropical Disease 5(1):1-6

5. Brand A, Hyphal growth in human fungal pathogens and its role in virulence. International journal of microbiology (2012) 2012

6. Cakir A et al (2004) Composition and antifungal activity of essential oils isolated from Hypericum hyssopifolium and Hypericum heterophyllum. Flavour Fragrance Journal 19(1):62-68

7. Alipieva K et al (2014) Verbascoside-A review of its occurrence,(bio) synthesis and pharmacological significance. Biotechnology advances 32(6):1065-1076

8. Pan J et al (2003) Pharmacological activities and mechanisms of natural phenylpropanoid glycosides. Die Pharmazie-An International Journal of Pharmaceutical Sciences 58(11):767-775

9. Li L et al (2005) Isolation and purification of acteoside and isoacteoside from Plantago psyllium L. by high-speed counter-current chromatography. Journal of chromatography A 1063(1-2):161-169

10. Agar OT, Cankaya IIT (2020) Analysis of phenylethanoids and their glycosidic derivatives, in Recent Advances in Natural Products Analysis. Elsevier, pp 221-254

11. Watson RR, Preedy VR (2016) Fruits, vegetables, and herbs: bioactive foods in health promotion. Academic Press

12. Jana S, Mandlekar S (2009) Role of phase II drug metabolizing enzymes in cancer chemoprevention. Curr Drug Metab 10(6):595-616

13. Ahmad M et al (1995) Acteoside: a new antihypertensive drug. Phytotherapy research 9(7):525-527

14. Aligiannis $\mathrm{N}$ et al (2003) Methanolic extract of Verbascum macrurum as a source of natural preservatives against oxidative rancidity. J Agric Food Chem 51(25):7308-7312 
15. Fuji $Y$ et al (2018) Chemical characterization and biological activity in young sesame leaves (Sesamum indicum L.) and changes in iridoid and polyphenol content at different growth stages. PloS one 13(3):e0194449

16. Cook CS et al (1993) Pharmacokinetics of a novel antiarrhythmic drug, actisomide. Pharmaceutical research 10(3):427-433

17. Dimberg LH, Theander O, Lingnert H (1993) Avenanthramides-a group of phenolic antioxidants in oats. Cereal Chem 70:637-637

18. Gulluce $\mathrm{M}$ et al (2006) Screening the antioxidant and antimicrobial properties of the lichens Parmelia saxatilis, Platismatia glauca, Ramalina pollinaria, Ramalina polymorpha and Umbilicaria nylanderiana. Phytomedicine 13(7):515-521

19. Kroon PA, Williamson G (1999) Hydroxycinnamates in plants and food: current and future perspectives. J Sci Food Agric 79(3):355-361

20. Morton RK, [6] Methods of extraction of enzymes from animal tissues. 1955

21. Taylor $\mathrm{J}$ et al (2001) Towards the scientific validation of traditional medicinal plants. Plant Growth Regul 34(1):23-37

22. Poole CF (2004) Chromatographic and spectroscopic methods for the determination of solvent properties of room temperature ionic liquids. Journal of chromatography A 1037(1-2):49-82

23. Tzschucke CC et al (2002) Modern separation techniques for the efficient workup in organic synthesis. Angew Chem Int Ed 41(21):3964-4000

24. Mustafa A, Turner C (2011) Pressurized liquid extraction as a green approach in food and herbal plants extraction: A review. Analytica chimica acta 703(1):8-18

25. Danlami U, Elisha EP (2017) A comparative study on the phytochemicals and antimicrobial activities of the ethanol and petroleum ether extracts of the leaves of Albizia Lebbeck and Its Mistletoe. International journal of pharmacy chemistry 3(2):13-18

26. Miller AL (1996) Antioxidant flavonoids: structure, function and clinical usage. Alt Med Rev 1(2):103111

27. Benzie IF, Strain JJ (1996) The ferric reducing ability of plasma (FRAP) as a measure of "antioxidant power": the FRAP assay. Anal Biochem 239(1):70-76

28. Gohari A et al., Antioxidant activity of some medicinal species using FRAP assay. 2011

29. Taylor $P$ et al (1983) Determination of minimum bactericidal concentrations of oxacillin for Staphylococcus aureus: influence and significance of technical factors. Antimicrob Agents Chemother 23(1):142-150

30. Owuama $\mathrm{Cl}$ (2017) Determination of minimum inhibitory concentration (MIC) and minimum bactericidal concentration (MBC) using a novel dilution tube method. African Journal of Microbiology Research 11(23):977-980

31. del M Contreras (2015) M., et al., Nano-liquid chromatography coupled to time-of-flight mass spectrometry for phenolic profiling: A case study in cranberry syrups. Talanta 132:929-938 
32. Muzitano MF et al (2006) The antileishmanial activity assessment of unusual flavonoids from Kalanchoe pinnata. Phytochemistry 67(18):2071-2077

33. Cengel Y, Heat TM (2003) A practical approach. McGraw-Hill, New York

34. Pragasam SJ, Rasool M (2013) Dietary component p-coumaric acid suppresses monosodium urate crystal-induced inflammation in rats. Inflamm Res 62(5):489-498

35. Perdicaris S, Vlachogianni T, Valavanidis A (2013) Bioactive natural substances from marine sponges: new developments and prospects for future pharmaceuticals. Nat Prod Chem Res 1(3):2329-6836

36. Rastogi $\mathrm{N}$ et al (1994) Potential drug targets for Mycobacterium avium defined by radiometric druginhibitor combination techniques. Antimicrob Agents Chemother 38(10):2287-2295

37. Williams LJ, Abdi H, Fisher's least significant difference (LSD) test. Encyclopedia of research design, 2010. 218: p. 840-853

38. Khan AM et al (2012) Flavonoids distribution in selected medicinal plants of Margalla hills and surroundings. Pak J Bot 44(4):1241-1245

39. Asahina Y, Shibata S, Chemistry of lichen substances. 1954

40. Shan B et al (2007) The in vitro antibacterial activity of dietary spice and medicinal herb extracts. International Journal of food microbiology 117(1):112-119

41. Lambert $R$ et al (2001) A study of the minimum inhibitory concentration and mode of action of oregano essential oil, thymol and carvacrol. J Appl Microbiol 91(3):453-462

42. Shearer $\mathrm{J}$ et al (2003) Quinides of roasted coffee enhance insulin action in conscious rats. J Nutr 133(11):3529-3532

43. Nikaido $\mathrm{H}$ et al (1998) Multidrug Efflux Pump AcrAB of Salmonella typhimuriumExcretes Only Those $\beta$-Lactam Antibiotics Containing Lipophilic Side Chains. J Bacteriol 180(17):4686-4692

44. Deans S, Ritchie G (1987) Antibacterial properties of plant essential oils. Int J Food Microbiol 5(2):165-180

45. Doerrler WT, Reedy MC, Raetz CR (2001) An Escherichia coli mutant defective in lipid export. J Biol Chem 276(15):11461-11464

46. Zink DL (1997) The impact of consumer demands and trends on food processing. Emerg Infect Dis 3(4):467

\section{Figures}




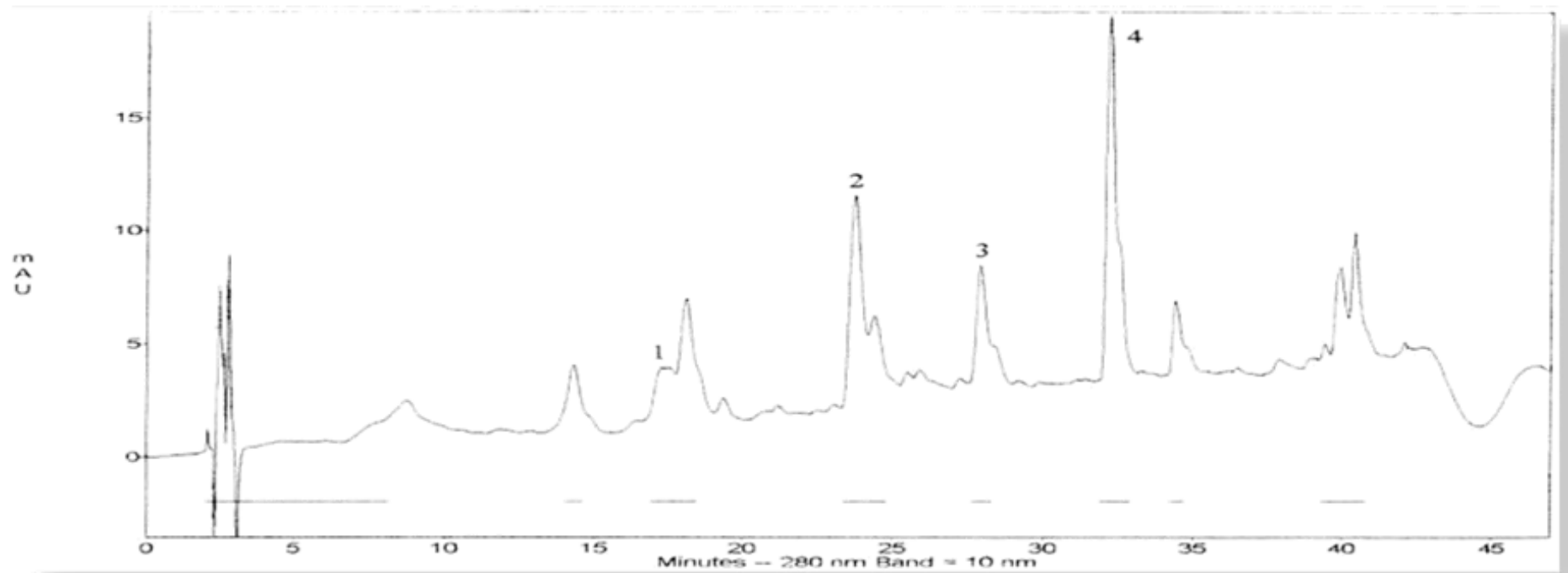

Figure 1

HPLC-DAD/MS/ chromatograph of phenolic compounds peaks indicated as follows (1) B-Sitosteryl linoleate (2) Myristyl diglucoside (3) 2 D-Triglucopyranoside (4) S-allylcysteine acid
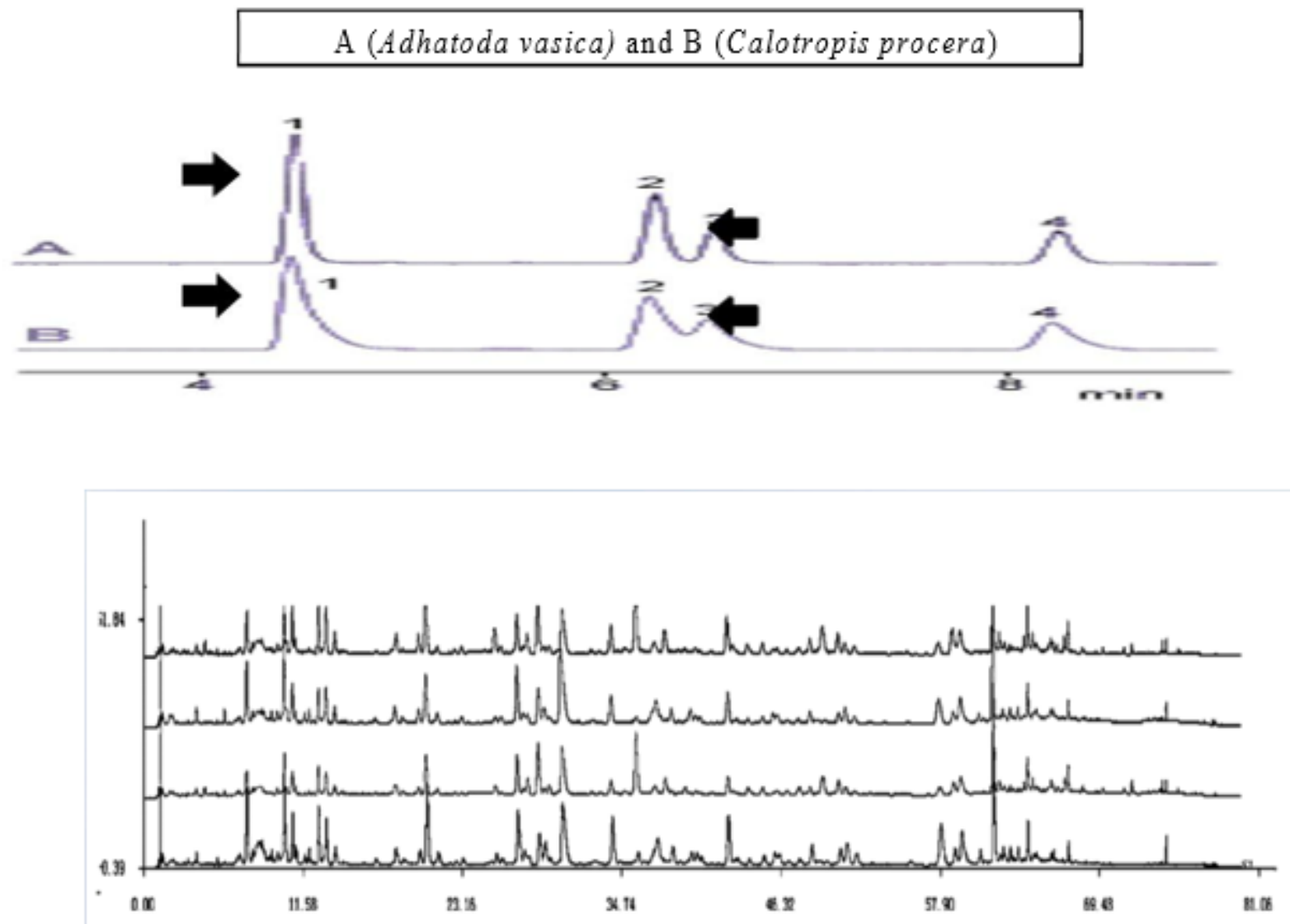

Figure 2 
Chemo-fingerprinting chromatograms of A (Adhatoda vasica) and B (Calotropis procera) as follows follows (1) B-Sitosteryl linoleate (2) Myristyl diglucoside (3) 2 D-Triglucopyranoside (4) S-allylcysteine acid

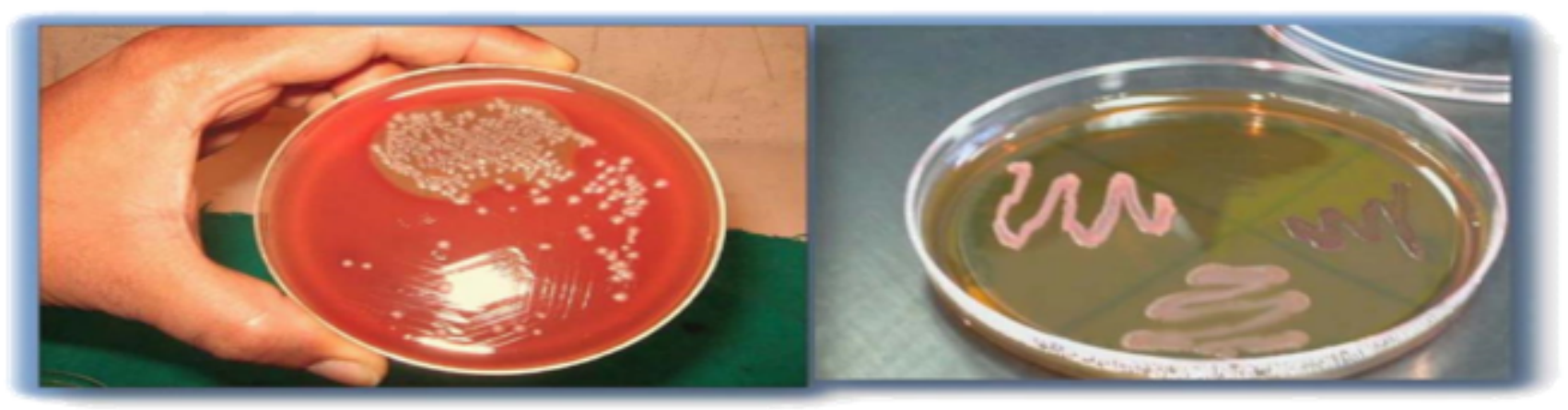

a Staphylococcus aureus

b Escherichia colf

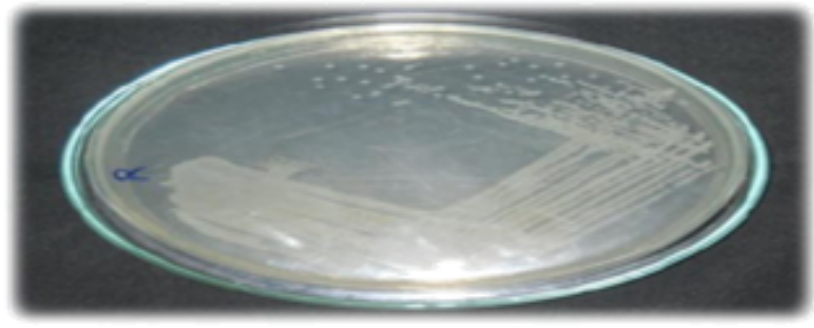

C Bacillus cereus

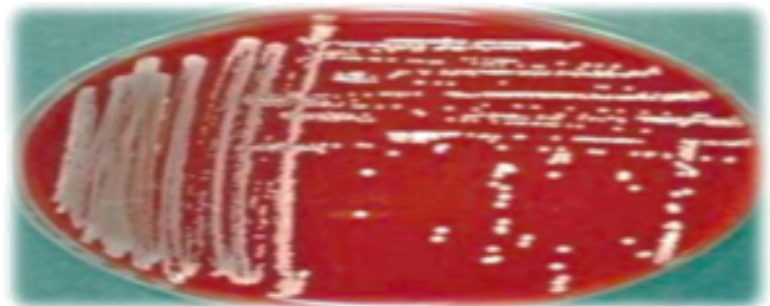

d Klebsiella numoneae

\section{Figure 3}

Agar diffusion method of MCB activities of ( $a, b, c$ and d) from Adhatoda vasica Calotropis procera species against the bacterial disease of Human body.

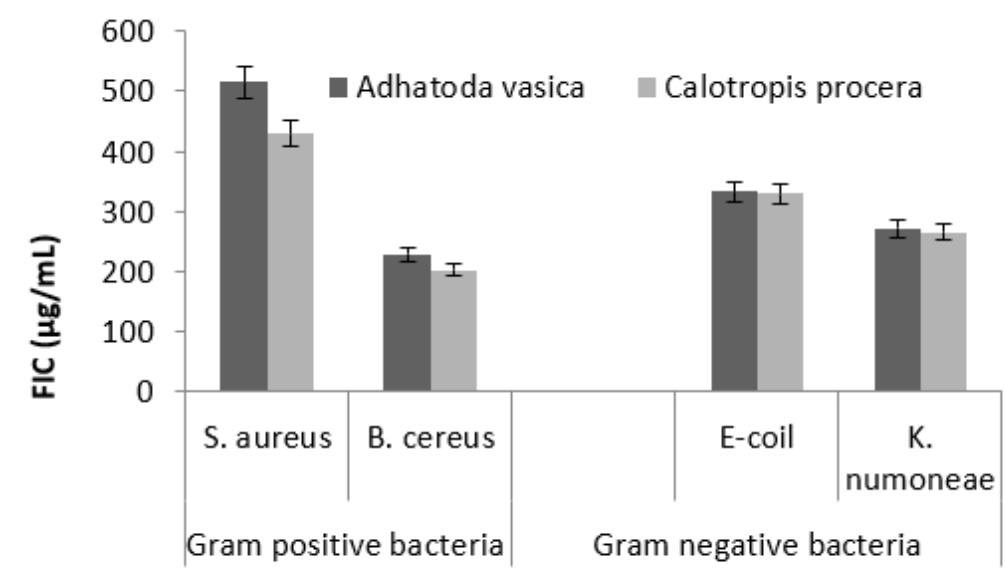

Bacteria Strain

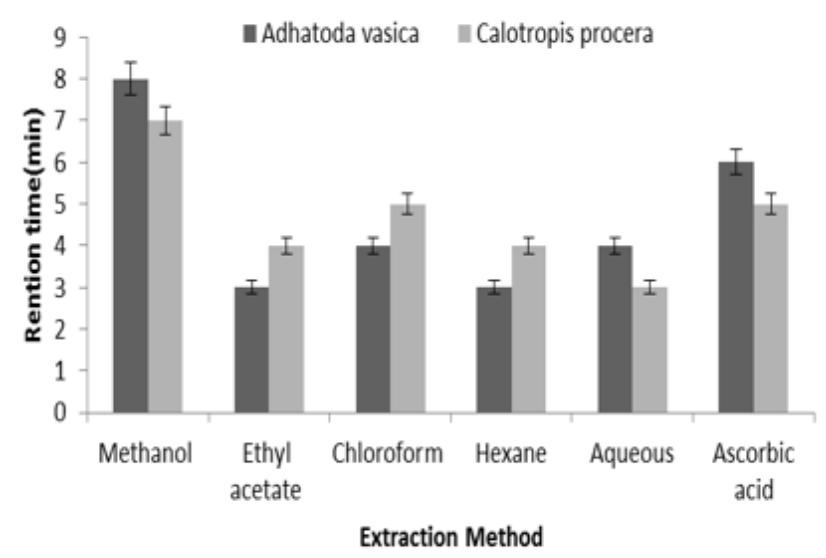

Extraction Method

\section{Figure 4}

Fractional inhibitory concentration (FIC) for different bacterial strains and HPLC-DAD/ MS Method of retention time (rt) with various solvents potentials of two herbal species Each vertical bar represents 
mean of three replicates \pm S.E.
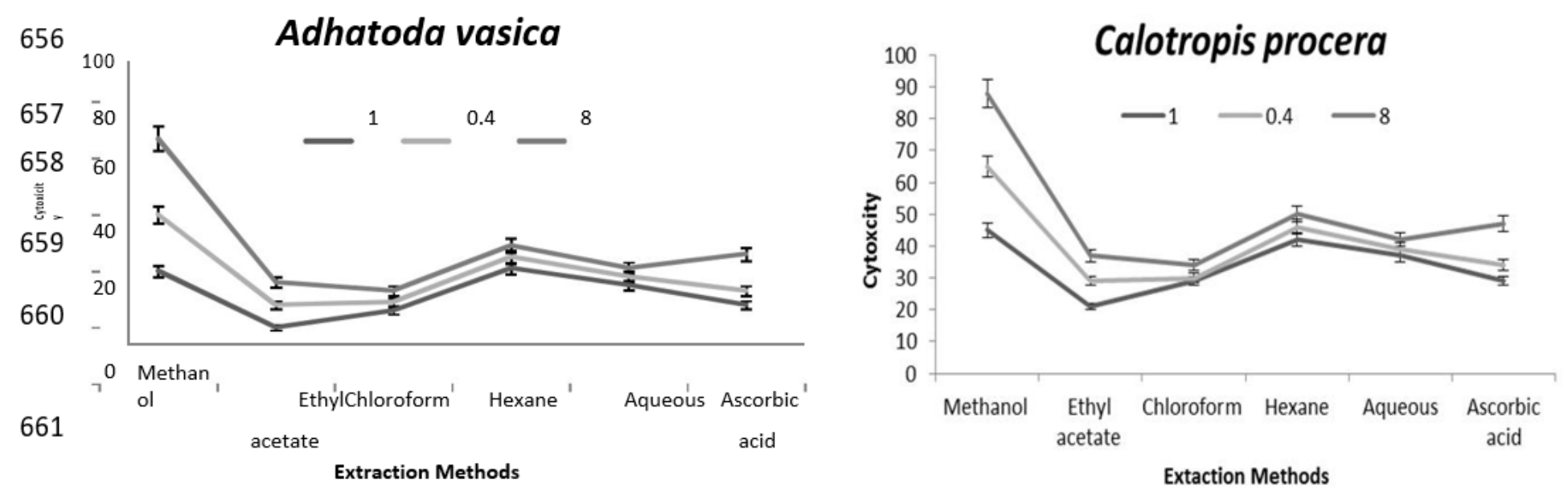

Figure 5

Potential Cytotoxicity level of two herbal species for controlling of toxins in different Bacterial strains. Each vertical bar represents mean of three replicates

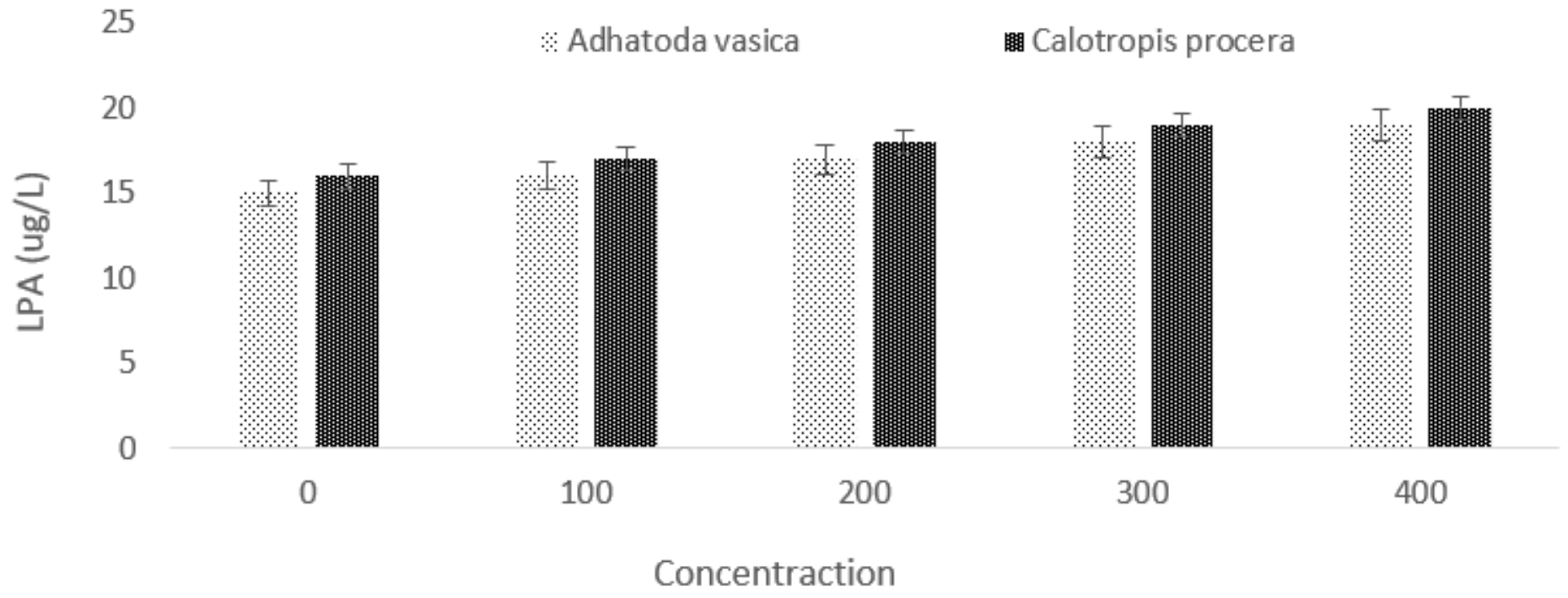

Figure 6

LPA activities from Adhatoda vasica Calotropis procera.

\section{Supplementary Files}

This is a list of supplementary files associated with this preprint. Click to download.

- supplementalfigure.png 